\title{
Effect of Tillage Practices on Selected Engineering Properties of Cassava (Manihot esculenta) Tubers
}

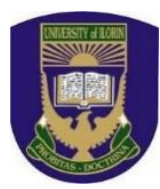

\author{
O. A. Adetola*, O. J. Olukunle, A. P. Olalusi, O. O. Olubanjo \\ Department of Agricultural Engineering, Federal University of Technology Akure, Nigeria.
}

ABSTRACT: The main objective of this study was to determine the influence of tillage practices on selected engineering properties of cassava tubers. Two field tests were conducted between May 2014 to April 2015 and May 2015 to April 2016. Eight tillage practices utilized for the experiment were coded as; Ploughing + Harrowing (A), Ploughing + Harrowing + Ridging (B), Manual Ridging (C), Minimum Tillage (D), Ploughing + Harrowing + Manual Digging to a depth of $30 \mathrm{~cm}+$ Sawdust of $10 \mathrm{~cm}$ depth set at the base (E), Ploughing + Harrowing + Ridging + Sawdust of $10 \mathrm{~cm}$ depth set at the base (F), Manual Ridging + Sawdust of $10 \mathrm{~cm}$ depth put at the base (G) and Manual Digging to a depth of $30 \mathrm{~cm}+$ Sawdust of $10 \mathrm{~cm}$ depth put at the base (H). TMS 0581 improved cassava variety and two fertilizer rates $622.50 \mathrm{~kg} / \mathrm{ha}$ and control were used. Randomized Complete Block Design was used. The experiment was $8 \times 2 \times 1$ factorial combinations in split-split plot design with three replications. The effect of different treatments on selected engineering properties of cassava tubers were determined. The results showed that Ploughing + Harrowing (A) tillage practice was significantly different from other tillage practices and gave the most suitable selected engineering properties of size $10.53 \pm 0.64^{\mathrm{c}} \mathrm{cm}$, surface area $371.15 \pm 45.53^{\mathrm{bc}} \mathrm{cm}^{2}$, sphericity $39.26 \pm 1.74^{\mathrm{a}} \mathrm{cm}$, roundness $21.40 \pm 3.29^{\mathrm{ab}}$, bulk mass $21.43^{\mathrm{h}} \mathrm{kg}$, coefficient of static friction $2.73 \pm 0.06^{\mathrm{abc}}$, compressive strain at break of $2.16 \pm 0.03^{\mathrm{e}} \mathrm{mm} / \mathrm{mm}$, compressive load at break of $11698.90 \pm 178.71^{\mathrm{f}} \mathrm{N}$, compressive stress at break of $2.72 \pm 0.04^{\mathrm{d}} \mathrm{MPa}$, energy at break of $191.62 \pm 2.93^{\mathrm{e}} \mathrm{J}$, modulus automatic of $1.89 \pm 0.031^{\mathrm{c}} \mathrm{MPa}$, followed by F, G, D, C, E, H and B tillage practices respectively. The study had provided some engineering properties for engineers to develop efficient agricultural machines for handling and processing of fresh cassava tubers.

Keywords: Evaluation, influence, tillage practices, engineering properties, cassava tubers.

\section{INTRODUCTION}

Tillage is a mechanical and control activity applied on soil to modify soil conditions for cultivating crops of higher yield. Tillage practice stifles weeds, controls soil disintegration and keeps up appropriate soil dampness (Koller, 2003). A decent, soil regulation suite keeps the soil from water and wind erosion, offers a decent weed free seedbed for planting, disrupts hardpans that may limit root growth and permits conservation and even a rise of organic matter (Wright et al., 2008). Tillage embraces all operations of seedbed preparations that optimize soil and environmental conditions for seed germination, seedling establishment and crop growth. Tillage includes mechanical methods based on conventional technologies of ploughing and harrowing, weed control using herbicides and fallowing with cover crops controlled by direct seeding through its residue mulch (Ohu, 2011).
Deep tillage breakdowns high density soil layer advances the water infiltration and drive in soil, boosts root growth, development and rises crop production potential (Bennie and Botha, 1986). Root and tuber crops retort contrarily to zero or minimum tillage. Jongruaysup et al (2007) stated that the new root yield of cassava (Manihot esculenta $C$.) cultivated under zero tillage practice was significantly higher than that of cassava cultivated using conventional tillage on fine loamy soil (Oxic Paleustults) in Thailand. In any case, in Khaw Hin Sorn and TTDI locations in Thailand, the cassava tuber yield was practically identical while in Huay Pong and Rayong districts of a comparative country most insignificant yield was obtained. Tongglum et al (2001) observed no significant difference in cassava root yield between zero and conventional planting in Thailand. In China, slight decline in cassava root yield anyway not at significant level was seen under minimum 
tillage system related to conventional tillage pracice (Weite $e t$ al., 1998).

A good knowledge on physical properties of designing information is required and critical in the development of machines, storage structures and processing (Esref and Halil, 2007). Mechanical properties of biological materials are the behavior of the materials under applied forces. The study of mechanical properties is required for textural assessment and better understanding of the product quality. Forcedeformation testing of agricultural materials can be utilized to consider the damage which occur during harvesting and handling of crops (Mohsenin, 2010).

Attempts at mechanizing the cassava peeling process have been made, however machines are yet to be completely developed (Kolawole et al., 2010) as no efficient cassava peeling machine is right now accessible in the market in Nigeria (Ohwovoriole et al., 1988; Adetan et al., 2003; Agbetoye, 2005; Oriola and Raji, 2013). This is brought about by irregular shape of the tubers and broad contrasts in the thickness of the strip, tuber size and weight crosswise over differing varieties of the tuber (Ezekwe, 1976; Adetan et al., 2006; Kamal and Oyelade, 2010).

A comprehensive information on the designing properties of the tuber is important to mechanize the cassava peeling process (Adetan et al., 2003). The absence of satisfactory information on the engineering properties of cassava tubers has been one of the major constraints in the development of an effective cassava tuber peeling machines. A few researchers (Ezekwe, 1979; Odigboh, 1983; Igbeka, 1980, 1984, 1985; Nanda and Matthew, 1996; Nwagugu and Okonkwo, 2009; Sajeev et al., 2009) made appreciable efforts on finding some of the properties of cassava that affects its processing as well as in the design of cassava handling and processing equipment.

The study is required to choose an efficient conservation and conventional tillage practice for better cassava production in the rain-fed regions of Nigeria, West Africa. In this study, effect of different tillage practices on cassava selected engineering properties have been evaluated.

\section{MATERIALS AND METHODS}

\section{A. Site Description}

Two field experiments were conducted between May 2014 to July 2015 and May 2015 to July 2016 on a plot of Teaching and Research Farm of the Federal University of Technology Akure $\left(7^{\circ} 15^{1} \mathrm{~N}, 5^{\circ} 15^{1} \mathrm{E}\right)$. Weather conditions during the growing period were recorded using digital thermometer, rain guage, hygrometer and barometer.

\section{B. Experimental Design}

Randomized Complete Block Design (RCBD) was used for the parent split-split plot factorial experiment. Eight tillage practices were used for the experiment and are coded in letters in order as: Ploughing + Harrowing (A), Ploughing + Harrowing + Ridging (B), Manual Ridging (C), Minimum Tillage (D), Ploughing + Harrowing + Manual Digging to a depth of $30 \mathrm{~cm}+$ Saw-dust of $10 \mathrm{~cm}$ depth put at the base (E), Ploughing + Harrowing + Ridging + Saw-dust of $10 \mathrm{~cm}$ depth set at the base subsequent to Ridging (F), Manual Ridging + Saw-dust of $10 \mathrm{~cm}$ depth set at the base (G) and Manual Digging to a depth of $30 \mathrm{~cm}+$ Saw-dust of $10 \mathrm{~cm}$ depth put at the base $(\mathrm{H})$.

Improved cassava variety TMS (Tropical Manihot Species) 0581 was acquired from Agricultural Development Project (ADP) Akure, Ondo State, Nigeria and was coded V. Two fertilizer rates (622.50 and 0$) \mathrm{kg} / \mathrm{ha}$ of NPK 15:15:15 were utilized and were coded F1 and F0 individually. Rain-fed cassava field was also coded Rfd. The tillage treatments and fertilizer rates were imposed on rain-fed cassava field of annual rainfall of $1365.48 \mathrm{~mm}$. The experiment was $8 \times 2 \times 1$ factorial combinations of tillage methods, fertilizer rates and rain-fed or irrigated scheme arranged in split-split plot design with three replications comprising eight tillage practices, two fertilizer rates and one cassava variety of three replications. The tillage methods constituted the main plot while fertilizer rate and soil moisture levels were the sub and sub-sub plots.

The treatment plots were $3 \times 3 \mathrm{~m}$ while the total field plot was $432 \mathrm{~m}^{2}$. A line spacing of 1 meter between the cassava plants was observed. Cassava stems of $20 \mathrm{~cm}$ long were planted at depth of $5-10 \mathrm{~cm}$. The cassava plants were harvested $10^{\text {th }}-11^{\text {th }}$ months after planting. Tables 2.1 and 2.2 presented the experimental design of the treatments and equations used for the determination of the physical properties of cassava tubers respectively. The effect of treatments on some physical and mechanical properties of cassava tubers were evaluated at the department of Agricultural Engineering, Federal University of Technology Akure (FUTA).

\section{Determination of Mechanical Properties of Cassava Tubers}

The physical properties of the cassava tubers were determined using standard formulae and equations as presented in Table 2 prior to the determination of the mechanical properties of the cassava tubers. The mechanical properties of cassava tubers were carried out at the research facility of Engineering Materials Development Institute (EMDI), Ondo Road, Akure, Ondo State Nigeria utilizing INSTRON 3369 Universal testing machine. A $2 \mathrm{~cm} \times 2 \mathrm{~cm}$ square shape of cassava tuber for each treatment was prepared and then subjected to compression test at loading rate of 30 $\mathrm{mm} / \mathrm{min}$. The compression test was carried out in triplicate for each of the treatment. The mechanical properties determined 
include compressive extension at break (standard), compressive strain at break(standard), compressive load at break (standard), compressive load at break (standard), energy at break (standard), extension at break (standard), compressive load at maximum compressive extension, compressive strain at maximum compressive extension, maximum compressive extension, compressive stress at maximum compressive extension, modulus (automatic), compressive load at yield (zero slope), compressive extension at yield (zero slope), compressive strain at yield (zero slope), compressive stress at yield (zero slope).

\section{Statistical Analysis}

Excel was used to compute the raw data. Descriptive and inferential statistics were used to analyze influence of tillage practices on the crop parameters. Duncan Multiple Range was used for Post hoc Test. Statistical Package for Social Science (SPSS 21 version) was utilized to analyze the data generated from this study.

Table 1: Experimental design of the treatments.

\begin{tabular}{|c|c|c|}
\hline Treatments & Description & Codes \\
\hline $\mathrm{T} 1$ & Ploughing + Harrowing + TMS 0581 + Rainfed + 622.50 kg/ha of NPK 15:15:15 manure & AVRfdF1 \\
\hline $\mathrm{T} 2$ & Ploughing + Harrowing + Ridging + TMS 0581 + Rainfed + 622.50 kg/ha of N PK 15:15:15 manure & BVRfdF1 \\
\hline $\mathrm{T} 3$ & Manual Ridging + TMS 0581 + Rainfed + 622.50 kg/ha of NPK 15:15:15 manure & CVRfdF1 \\
\hline $\mathrm{T} 4$ & Minimum Tillage + TMS 0581 + Rainfed + 622.50 kg/ha of NPK 15:15:15 manure & DVRfdF1 \\
\hline T5 & $\begin{array}{l}\text { Ploughing + Harrowing + Manual Digging to a depth of } 30 \mathrm{~cm}+\text { Sawdust of } 10 \mathrm{~cm} \text { depth placed at the base after Manual } \\
\text { Digging + TMS 0581 + Rainfed + 622.50 kg/ha of NPK 15:15:15 manure }\end{array}$ & EVRfdF1 \\
\hline T6 & $\begin{array}{l}\text { Ploughing + Harrowing + Ridging + Sawdust of } 10 \mathrm{~cm} \text { depth placed at the base after Ridging }+ \text { TMS } 0581+\text { Rainfed }+ \\
622.50 \mathrm{~kg} / \mathrm{ha} \text { of N PK 15:15:15 manure }\end{array}$ & FVRfdF1 \\
\hline $\mathrm{T} 7$ & $\begin{array}{l}\text { Manual Ridging + Sawdust of } 10 \mathrm{~cm} \text { depth placed at the base after Manual Ridging }+ \text { TMS } 0581+\mathrm{Rainfed}+622.50 \mathrm{~kg} / \mathrm{ha} \\
\text { of NPK 15:15:15 manure }\end{array}$ & GVRfdF1 \\
\hline T8 & $\begin{array}{l}\text { Manual Digging to a depth of } 30 \mathrm{~cm}+\text { Sawdust of } 10 \mathrm{~cm} \text { depth placed at the base after Manual Digging }+ \text { TMS } 0581+ \\
\text { Rainfed }+622.50 \mathrm{~kg} / \mathrm{ha} \text { of NPK 15:15:15 manure }\end{array}$ & HVRfdF1 \\
\hline T9 & Ploughing + Harrowing + TMS 0581 + Rainfed + $0 \mathrm{~kg} / \mathrm{ha}$ of NPK 15:15:15 manure & AVRfdF0 \\
\hline $\mathrm{T} 10$ & Ploughing + Harrowing + Ridging + TMS 0581 + Rainfed + 0 kg/ha of NPK 15:15:15 manure & BVRfdF0 \\
\hline T11 & Manual Ridging + TMS 0581 + Rainfed + 0 kg/ha of NPK 15:15:15 manure & CVRfdF0 \\
\hline T12 & Minimum Tillage + TMS 0581 + Rainfed + 0 kg/ha of NPK 15:15:15 manure & DVRfdF0 \\
\hline T13 & $\begin{array}{l}\text { Ploughing + Harrowing + Manual Digging to a depth of } 30 \mathrm{~cm}+\text { Sawdust of } 10 \mathrm{~cm} \text { depth placed at the base after Manual } \\
\text { Digging + TMS 0581 + Rainfed + 0 kg/ha of NPK 15:15:15 manure }\end{array}$ & EVRfdF0 \\
\hline T14 & $\begin{array}{l}\text { Ploughing }+ \text { Harrowing }+ \text { Ridging }+ \text { Sawdust of } 10 \mathrm{~cm} \text { depth placed at the base after Ridging }+ \text { TMS } 0581+\text { Rainfed }+0 \\
\mathrm{~kg} / \text { ha of NPK 15:15:15 manure }\end{array}$ & FVRfdF0 \\
\hline $\mathrm{T} 15$ & $\begin{array}{l}\text { Manual Ridging }+ \text { Sawdust of } 10 \mathrm{~cm} \text { depth placed at the base after Manual Ridging }+ \text { TMS } 0581+\mathrm{Rainfed}+0 \mathrm{~kg} / \mathrm{ha} \text { of } \\
\text { NPK 15:15:15 manure }\end{array}$ & GVRfdF0 \\
\hline T16 & $\begin{array}{l}\text { Manual Digging to a depth of } 30 \mathrm{~cm}+\text { Sawdust of } 10 \mathrm{~cm} \text { depth placed at the base after Manual Digging }+ \text { TMS } 0581+ \\
\text { Rainfed }+0 \mathrm{~kg} / \mathrm{ha} \text { of NPK 15:15:15 manure }\end{array}$ & HVRfdF0 \\
\hline
\end{tabular}


Table 2: Determination of physical properties of cassava tubers.

\begin{tabular}{|c|c|c|}
\hline Property & Method or equation for determining of physical properties & Reference \\
\hline $\mathrm{L}$ & Measuring tape & Olukunle and Akinnuli, 2012 \\
\hline $\mathrm{W}$ & Digital vernier caliper & Olukunle and Akinnuli, 2012 \\
\hline $\mathrm{T}$ & $\begin{array}{l}\text { Measuring three different segments of the cassava tubers using digital vernier } \\
\text { caliper }\end{array}$ & Olukunle and Akinnuli, 2012. \\
\hline $\mathrm{D}_{\mathrm{g}}$ & $D_{g}=(L W T)^{1 / 3}$ & $\begin{array}{l}\text { Ozguven and Vursavus (2005); Akaaimo and } \\
\text { Raji (2006). }\end{array}$ \\
\hline $\mathrm{R}_{\mathrm{a}}$ & $\mathrm{W} / \mathrm{T} 100 \%$ & Burum, 2004. \\
\hline $\mathrm{S}_{\mathrm{a}}$ & $\mathrm{S}_{\mathrm{a}}=\pi D_{g}^{2}$ & $\begin{array}{l}\text { Yalcin et al. } 2007 \text { and Olukunle and } \\
\text { Akinnuli, } 2012 .\end{array}$ \\
\hline $\mathrm{S}_{\mathrm{p}}$ & $S_{p}=\frac{(L W T)^{1 / 3}}{L} 100 \%$ & $\begin{array}{l}\text { Yalcin et al. } 2007 \text { and Olukunle and } \\
\text { Akinnuli, } 2012 .\end{array}$ \\
\hline $\mathrm{R}_{\mathrm{o}}$ & $R_{o}=\frac{A_{P}}{A_{C}}$ & $\begin{array}{l}\text { Yalcin et al. } 2007 \text { and Olukunle and } \\
\text { Akinnuli, } 2012 .\end{array}$ \\
\hline$\alpha$ & $\begin{array}{l}\text { The apparatus consisting of plywood box with a fixed stand attached with a } \\
\text { protractor and an adjustable plate at the surface }\end{array}$ & Tabatabaeefar, 2003. \\
\hline$\mu$ & $\mu=\tan \alpha$ & $\begin{array}{l}\text { Yalcin et al. } 2007 \text { and Olukunle and } \\
\text { Akinnuli, } 2012 .\end{array}$ \\
\hline $\mathrm{m}$ & $\begin{array}{l}\text { A digital weighing balance } 10 \mathrm{~kg} \text { was used in weighing each of the cassava } \\
\text { tubers }\end{array}$ & $\begin{array}{l}\text { Yalcin et al. } 2007 \text { and Olukunle and } \\
\text { Akinnuli, } 2012 .\end{array}$ \\
\hline $\mathrm{V}_{\mathrm{t}}$ & $\begin{array}{l}\text { By putting a known mass of a (unit) sample into a cylindrical container of water, } \\
\text { change in level of the liquid in the cylinder gives the unit volume }\end{array}$ & Ozguven and Vursavus 2005 \\
\hline$\rho_{t}$ & $\rho_{t}=\frac{W_{t}}{V_{t}}$ & $\begin{array}{l}\text { Akaaimo and Raji (2006) and Yalcin et al. } \\
2007\end{array}$ \\
\hline$\rho_{b}$ & $\rho_{b}=\frac{W_{s}}{V_{s}}$ & $\begin{array}{l}\text { Akaaimo and Raji (2006) and Yalcin et al. } \\
2007\end{array}$ \\
\hline bm & By weighing together all the cassava in a bucket & Olukunle and Akinnuli, 2012. \\
\hline bv & $\begin{array}{l}\text { The whole sample in a stand was put into the cylindrical container of water, and } \\
\text { the change in level of the liquid in the cylinder }\end{array}$ & Ozguven and Vursavus 2005. \\
\hline$\varepsilon$ & $\varepsilon=\left(1-\frac{\rho_{b}}{\rho_{t}}\right) \times 100$ & Akaaimo and Raji 2006. \\
\hline
\end{tabular}

where $\mathrm{D}_{\mathrm{g}}$ is the equivalent diameter; $\mathrm{L}$ is the length; $\mathrm{W}$ is the width and T is the thickness, $\mathrm{R}_{\mathrm{a}}$ is the aspect ratio; $S_{a}$ is the surface area; $\mathrm{S}_{\mathrm{p}}$ is the sphericity; $\mathrm{R}_{\mathrm{o}}$ is the roundness; $A_{p}$ is the largest projected area of object in natural resting position; $A_{c}$ is the area of the smallest circumscribing circle; $\mu$ is the coefficient of static friction and $\alpha$ is the angle of repose; $\rho_{t}$ is the true density; $\mathrm{W}_{\mathrm{t}}$ is the true weight; $\mathrm{m}$ is the mass; $\mathrm{V}_{\mathrm{t}}$ is the true volume; bm is the bulk mass; bv is the bulk volume; $\rho_{b}$ is the bulk density in $\mathrm{kg} / \mathrm{m}^{3} ; W_{s}$ is the weight of the sample in $\mathrm{kg} ; V_{s}$ is the volume occupied by the sample in $m^{3} ; \varepsilon$ is the porosity, $\rho_{t}$ is the true density and $\rho_{b}$ is the bulk density.

\section{RESULTS AND DISCUSSION}

The effect of tillage practices on physical of TMS 0581 cassava tubers for a rain fed soil $+622.50 \mathrm{Kg} / \mathrm{Ha}$ fertilizer for 2014/2015 Planting Season are presented in Tables 3-8 whereas the mechanical Properties of the cassava tubers are presented in Figures 1a-1h and 2a-2h respectively.
A. Influence of Tillage Practices on Physical Properties of TMS 0581 Cassava Tubers under a Rain-fed Soil + 622.50 kg/ha Fertilizer 2014/2015.

The influence of different tillage treatment plots on physical properties of TMS 0581 cassava tubers under a rainfed $+622.50 \mathrm{~kg} / \mathrm{ha}$ fertilizer for planting season 2014/2015 are presented in Table 3. There was significant $(\mathrm{p}<0.05)$ difference of tillage practices on size of cassava tubers. Ploughing + Harrowing + Ridging + Sawdust of $10 \mathrm{~cm}$ depth 
placed at the base after Ridging $(\mathrm{F})$ tillage practice gave the highest size $10.66 \pm 0.91^{\mathrm{c}} \mathrm{cm}$, followed by A, E, D, G, B and H tillage practices respectively while $\mathrm{C}$ tillage practice offered the lowest size of $7.50 \pm 0.82^{\mathrm{a}} \mathrm{cm}$. Tillage method improves the physical state of the soil by manipulating and pulverization the soil (Kolawole et al., 2010, Oriola and Raji, 2013; Ahmad et al., 1996; Mahajan, 1996; Hammel, 1989). There was significant $(\mathrm{p}<0.05)$ on surface area of cassava tubers. F tillage practice gave the maximum surface area of $383.47 \pm 62.09^{\circ}$ $\mathrm{cm}^{2}$, trailed by A, E, D, G, H respectively but C tillage practice offered the minimum surface area of $200.21 \pm 38.96^{\mathrm{a}} \mathrm{cm}^{2}$. Tillage prepared a good seedbed in which if the crop is placed can grow satisfactory for development and growth. The results corroborate result obtained by other researchers (Kolawole et al., 2010; Oriola and Raji, 2013).

There was significant $(\mathrm{p}<0.05)$ effect of tillage practices on sphericity of cassava tubers. $H$ tillage practice offered the uppermost sphericity of $51.58 \pm 3.82^{\mathrm{b}} \%$, tailed by F, C, D, E, $A$ and $B$ tillage practices respectively although $G$ tillage practice provided the lowermost sphericity of $37.24 \pm 4.22^{\mathrm{a}} \%$. Earlier study by (Adetan et al., 2006; Kamal and Oyelade, 2010) also supports the results of this study. B tillage practice presented the peak roundness of $23.20 \pm 3.83^{\mathrm{b}}$, tracked by $\mathrm{G}, \mathrm{A}$, $\mathrm{E}, \mathrm{D}, \mathrm{F}$ and $\mathrm{H}$ tillage practices however $\mathrm{C}$ tillage treatment offered the lowermost roundness of $10.60 \pm 3.03^{\mathrm{a}}$. Thus, B tillage practice will enhance uniform roundness of cassava tubers (Ohwovoriole et al., 1988).

Tillage practice (A) furnished the uppermost bulk mass of $21.43^{\mathrm{h}} \mathrm{kg}$, tailed by F, G, D, C, E and H tillage treatments respectively although $\mathrm{C}$ tillage treatment presented the lowermost bulk mass of $3.17^{\mathrm{a}} \mathrm{kg}$. Choice of an appropriate tillage practice for crop generation is critical for best development and yield.

B. The Effect of Tillage Methods on Mechanical Properties of TMS 0581 Cassava Tubers under the Rain-fed + $622.50 \mathrm{~kg} / \mathrm{ha}$ Fertilizer for Planting Season 2014/2015.

The effect of tillage practices on mechanical properties of TMS 0581 cassava tubers for a rain-fed $+622.50 \mathrm{~kg} / \mathrm{ha}$ fertilizer for planting season 2014/2015 are presented in Table 4 . There was significant $(p<0.05)$ effect of tillage treatments on the mechanical properties of cassava tubers. Fresh root cassava tubers of A tillage practice offered the most suitable selected engineering properties respectively, tailed by F, G, D, $\mathrm{C}, \mathrm{E}, \mathrm{H}$ and $\mathrm{B}$ tillage practices. The behavior of the materials under applied forces. These results agree with the findings of other researchers (Mohsenin, 2010).

Table 3: Influence of tillage practices on physical properties of TMS 0581 cassava tubers under a rain fed soil $+622.50 \mathrm{~kg} / \mathrm{ha}$ fertilizer.

\begin{tabular}{|c|c|c|c|c|c|c|c|c|}
\hline Parameters & $\mathbf{A}$ & B & $\mathbf{C}$ & D & $\mathbf{E}$ & $\mathbf{F}$ & $\mathbf{G}$ & $\mathbf{H}$ \\
\hline $\mathrm{L}(\mathrm{cm})$ & $28.02 \pm 2.18^{\mathrm{ab}}$ & $22.82 \pm 2.34^{\mathrm{ab}}$ & $17.48 \pm 1.89^{\mathrm{ab}}$ & $23.26 \pm 2.60^{\mathrm{ab}}$ & $25.43 \pm 3.25^{\mathrm{ab}}$ & $23.00 \pm 3.13^{\mathrm{ab}}$ & $29.89 \pm 3.95^{b}$ & $18.30 \pm 2.34^{\mathrm{a}}$ \\
\hline $\mathrm{W}(\mathrm{cm})$ & $6.47 \pm 0.45^{\mathrm{ab}}$ & $5.86 \pm 0.31^{\mathrm{a}}$ & $5.98 \pm 0.49^{\mathrm{a}}$ & $6.49 \pm 0.51^{\mathrm{ab}}$ & $6.56 \pm 0.44^{\mathrm{ab}}$ & $7.82 \pm 0.56^{\mathrm{b}}$ & $5.85 \pm 0.33^{\mathrm{a}}$ & $6.39 \pm 0.39^{\mathrm{ab}}$ \\
\hline $\mathrm{T}(\mathrm{cm})$ & $6.63 \pm 0.40^{\mathrm{b}}$ & $4.91 \pm 0.26^{\mathrm{ab}}$ & $4.76 \pm 0.65^{\mathrm{a}}$ & $5.96 \pm 0.35^{\mathrm{ab}}$ & $6.15 \pm 0.43^{\mathrm{b}}$ & $6.96 \pm 0.45^{b}$ & $5.21 \pm 0.29^{\mathrm{ab}}$ & $5.57 \pm 0.29^{\mathrm{ab}}$ \\
\hline $\mathrm{DG}(\mathrm{cm})$ & $10.53 \pm 0.64^{\mathrm{c}}$ & $8.63 \pm 0.48^{\mathrm{ab}}$ & $7.50 \pm 0.82^{\mathrm{a}}$ & $9.56 \pm 0.65^{\mathrm{ab}}$ & $10.01 \pm 0.82^{\mathrm{c}}$ & $10.66 \pm 0.91^{\mathrm{c}}$ & $9.40 \pm 0.56^{\mathrm{ab}}$ & $8.53 \pm 0.62^{\mathrm{ab}}$ \\
\hline $\mathrm{AR}(\%)$ & $24.82 \pm 1.87^{\mathrm{a}}$ & $27.06 \pm 2.42^{\mathrm{ab}}$ & $36.66 \pm 3.97^{\mathrm{c}}$ & $29.53 \pm 2.59^{\mathrm{ab}}$ & $27.86 \pm 2.68^{\mathrm{ab}}$ & $38.09 \pm 3.39^{c}$ & $25.41 \pm 4.58^{\mathrm{ab}}$ & $40.43 \pm 4.27^{\mathrm{c}}$ \\
\hline $\mathrm{SA}\left(\mathrm{cm}^{2}\right)$ & $371.15 \pm 45.53^{\mathrm{bc}}$ & $239.35 \pm 28.11^{\mathrm{a}}$ & $200.21 \pm 38.96^{\mathrm{a}}$ & $299.49 \pm 37.55^{\mathrm{ab}}$ & $331.73 \pm 49.97^{\mathrm{abc}}$ & $383.47 \pm 62.09^{\mathrm{c}}$ & $290.89 \pm 35.47^{\mathrm{a}}$ & $241.94 \pm 37.65^{\mathrm{ab}}$ \\
\hline $\mathrm{SP}(\%)$ & $39.26 \pm 1.74^{\mathrm{a}}$ & $39.08 \pm 2.19^{\mathrm{a}}$ & $45.02 \pm 4.36^{\mathrm{ab}}$ & $42.66 \pm 2.04^{\mathrm{ab}}$ & $41.37 \pm 2.47^{\mathrm{ab}}$ & $50.23 \pm 3.11^{b}$ & $37.24 \pm 4.22^{\mathrm{a}}$ & $51.58 \pm 3.82^{b}$ \\
\hline $\mathrm{R}$ & $21.40 \pm 3.29^{\mathrm{ab}}$ & $23.20 \pm 3.83^{\mathrm{b}}$ & $10.60 \pm 3.03^{\mathrm{a}}$ & $15.21 \pm 2.19^{\mathrm{ab}}$ & $21.25 \pm 5.49^{\mathrm{ab}}$ & $13.17 \pm 2.53^{\mathrm{ab}}$ & $21.56 \pm 4.59^{\mathrm{ab}}$ & $12.56 \pm 2.68^{\mathrm{ab}}$ \\
\hline $\mathrm{M}(\mathrm{kg})$ & $1.17 \pm 0.23^{\mathrm{b}}$ & $0.39 \pm 0.10^{\mathrm{a}}$ & $0.49 \pm 0.13$ & $0.69 \pm 0.16^{\mathrm{ab}}$ & $0.68 \pm 0.14^{\mathrm{ab}}$ & $0.84 \pm 0.23^{\mathrm{ab}}$ & $0.56 \pm 0.10^{\mathrm{a}}$ & $0.39 \pm 0.09^{\mathrm{a}}$ \\
\hline $\mathrm{V}\left(\mathrm{m}^{3}\right)$ & $1.23 \pm 0.24^{\mathrm{b}}$ & $0.42 \pm 0.09^{\mathrm{a}}$ & $0.48 \pm 0.12^{\mathrm{a}}$ & $0.65 \pm 0.16$ & $0.60 \pm 0.13^{\mathrm{a}}$ & $0.74 \pm 0.21^{\mathrm{ab}}$ & $0.49 \pm 0.09^{\mathrm{a}}$ & $0.33 \pm 0.09^{\mathrm{a}}$ \\
\hline $\mathrm{TD}\left(\mathrm{kg} / \mathrm{m}^{3}\right)$ & $0.94 \pm 0.02^{\mathrm{a}}$ & $0.95 \pm 0.08^{\mathrm{ab}}$ & $0.99 \pm 0.08^{\mathrm{ab}}$ & $1.07 \pm 0.04^{\mathrm{bc}}$ & $1.17 \pm 0.03^{c}$ & $1.17 \pm 0.02^{\mathrm{c}}$ & $1.17 \pm 0.01^{\mathrm{c}}$ & $1.20 \pm 0.02^{\mathrm{cl}}$ \\
\hline BM (kg) & $21.43^{\mathrm{h}}$ & $3.17^{\mathrm{a}}$ & $5.96^{\mathrm{d}}$ & $7.07^{\mathrm{e}}$ & $5.54^{\mathrm{c}}$ & $9.33^{\mathrm{g}}$ & $7.95^{\mathrm{f}}$ & $4.76^{\mathrm{b}}$ \\
\hline $\mathrm{BV}\left(\mathrm{m}^{3}\right)$ & $20.70^{\mathrm{h}}$ & $2.80^{\mathrm{a}}$ & $5.40^{\mathrm{d}}$ & $6.20^{\mathrm{e}}$ & $5.01^{\mathrm{c}}$ & $8.44^{\mathrm{g}}$ & $7.20^{\mathrm{f}}$ & $4.31^{\mathrm{b}}$ \\
\hline $\mathrm{BD}\left(\mathrm{kg} / \mathrm{m}^{3}\right)$ & $1.04^{\mathrm{a}}$ & $1.13^{\mathrm{e}}$ & $1.10^{\mathrm{b}}$ & $1.14^{\mathrm{f}}$ & $1.11^{\mathrm{d}}$ & $1.11^{\mathrm{c}}$ & $1.11^{\mathrm{c}}$ & $1.11^{\mathrm{c}}$ \\
\hline $\mathrm{P}(\%)$ & $11.78 \pm 3.19^{\mathrm{ab}}$ & $24.74 \pm 11.09^{\mathrm{a}}$ & $23.90 \pm 15.28^{a}$ & $7.51 \pm 5.25^{\mathrm{ab}}$ & $4.72 \pm 2.50^{\mathrm{b}}$ & $5.15 \pm 1.55^{\mathrm{b}}$ & $4.62 \pm 1.08^{b}$ & $7.52 \pm 1.39^{\mathrm{b}}$ \\
\hline $\operatorname{AP}\left({ }^{0}\right)$ & $69.78 \pm 0.38^{\mathrm{bc}}$ & $70.00 \pm 0.42^{\mathrm{bc}}$ & $68.41 \pm 0.42^{\mathrm{ab}}$ & $69.20 \pm 0.29^{\mathrm{bc}}$ & $69.00 \pm 0.50^{\mathrm{ab}}$ & $68.09 \pm 0.46^{\mathrm{a}}$ & $70.64 \pm 0.72^{\text {cd }}$ & $71.75 \pm 0.45^{\mathrm{d}}$ \\
\hline $\mathrm{CF}$ & $2.73 \pm 0.06^{\mathrm{abc}}$ & $2.75 \pm 0.06^{\mathrm{bc}}$ & $2.54 \pm 0.05^{\mathrm{ab}}$ & $2.64 \pm 0.04^{\mathrm{ab}}$ & $2.62 \pm 0.07^{\mathrm{ab}}$ & $2.50 \pm 0.06^{\mathrm{a}}$ & $2.89 \pm 0.11^{\mathrm{cd}}$ & $3.05 \pm 0.08^{\mathrm{d}}$ \\
\hline
\end{tabular}

Values are means for triplicates and standard error. Means values including distinctive superscript inside a similar line are altogether significant ( $\mathrm{P}<0.05)$. $\mathrm{L}$ is the length in $\mathrm{cm}, \mathrm{W}$ is the width in $\mathrm{cm}, \mathrm{T}$ is the thickness in $\mathrm{cm}, \mathrm{DG}$ is the size in $\mathrm{cm}, \mathrm{AR}$ is the aspect ratio in $\%, \mathrm{SA}$ is the surface area in $\mathrm{cm}^{2}, \mathrm{SP}$ is the sphericity in $\mathrm{cm}, \mathrm{R}$ is the roundness, $\mathrm{M}$ is the unit mass in $\mathrm{kg}, \mathrm{V}$ is the unit volume in $\mathrm{m}^{3}$, TD is the true density in $\mathrm{kg} / \mathrm{m}^{3}, \mathrm{BM}$ is the bulk mass in $\mathrm{kg}, \mathrm{BV}$ is the bulk volume in $\mathrm{m}^{3}$, BD is the bulk density in $\mathrm{kg} / \mathrm{m}^{3}, \mathrm{P}$ is the porosity in $\%$, AP is the angle of repose in ${ }^{0}$ and $\mathrm{CF}$ is the coefficient of static friction. 
NIGERIAN JOURNAL OF TECHNOLOGICAL DEVELOPMENT, VOL. 17, NO.3, SEPTEMBER 2020

Table 4: Effect of tillage practices on mechanical properties of TMS 0581 cassava tubers under the rain fed soil $+622.50 \mathrm{~kg} / \mathrm{ha}$ fertilizer

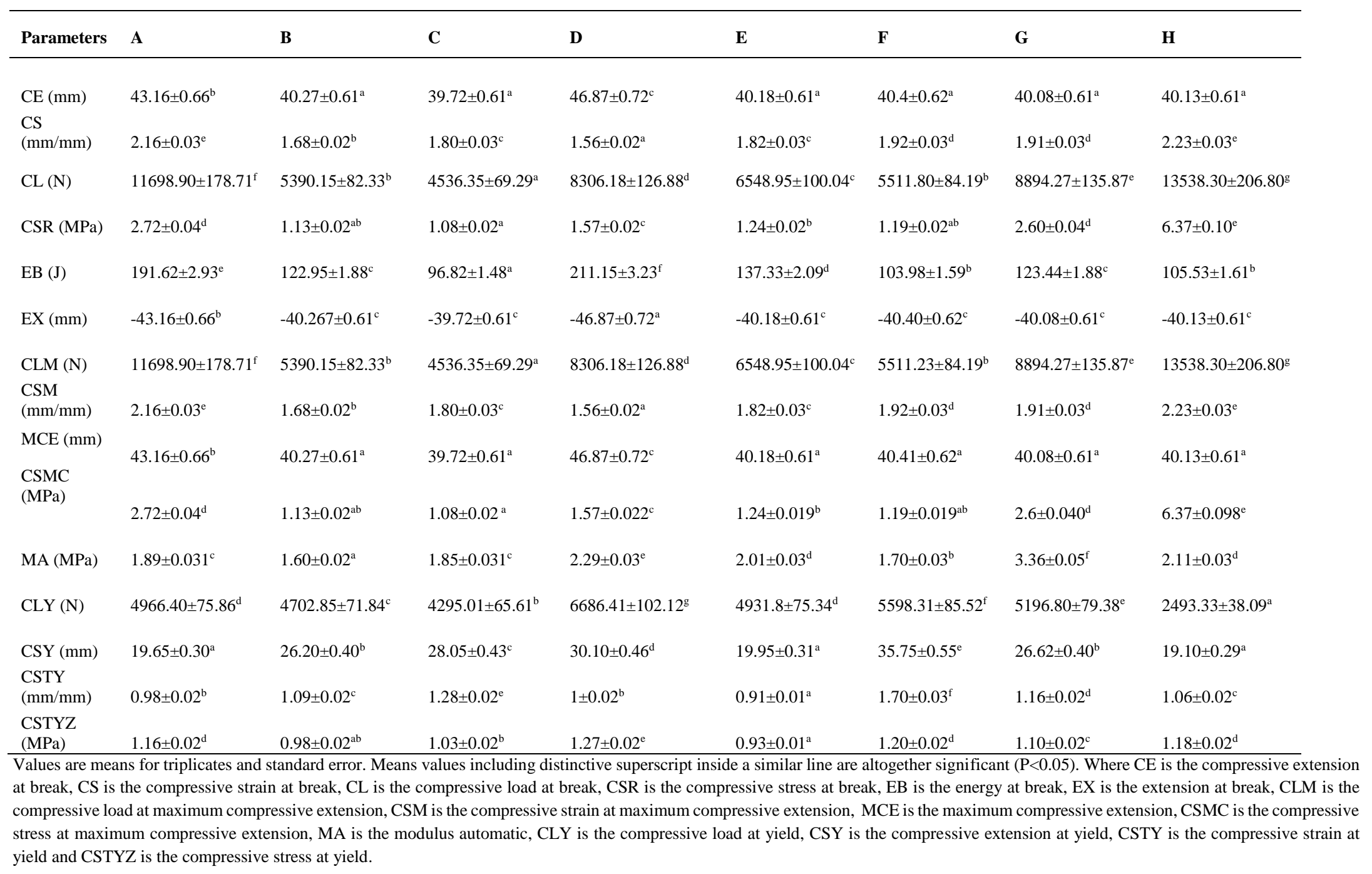


C. The Effect of Tillage methods on Compressive Test of TMS 0581 Cassava Tubers under the Rain-fed $+622.50 \mathrm{~kg} / \mathrm{ha}$ Fertilizer for Planting Season $2014 / 2015$.

The result of tillage practices on compressive test of TMS 0581 cassava tubers for a rain-fed $+622.50 \mathrm{~kg} / \mathrm{ha}$ fertilizer for planting season 2014/2015 are shown in Figure 1. The results showed that the compressive load at maximum compressive extension are approximately (11700, 5390, 4540, $8300,6500,5500,8900$ and 13500$) \mathrm{N}$ respectively however the compressive extension at break (standard) are about $(43,40,40,47,40,40,40$ and 40$) \mathrm{mm}$ correspondingly for A, B, C, D, E, F, G and $\mathrm{H}$ tillage practices respectively. All the eight tillage practices gave almost the same value of compressive extension at break (standard) at different compressive load at break (standard)

\section{A}

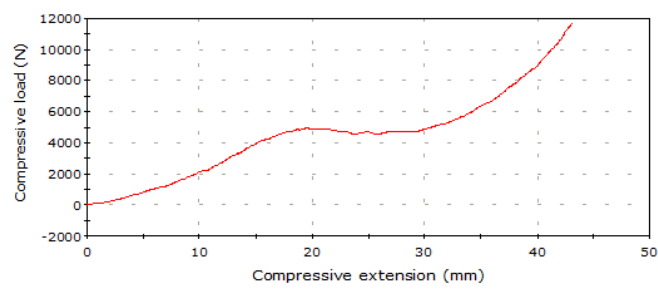

A

Figure 1a: Influence of Tillage Practice A on Compression Test of TMS 0581 Cassava Tubers for a Rain Fed Soil $+622.50 \mathrm{~kg} / \mathrm{ha}$ Fertilizer.

B

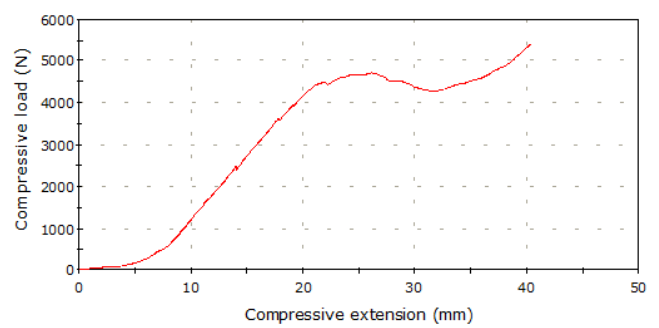

B

Figure 1b: Influence of Tillage Practice B on Compression Test of TMS 0581 Cassava Tubers for a Rain Fed Soil + $622.50 \mathrm{~kg} / \mathrm{ha}$ Fertilizer.

C

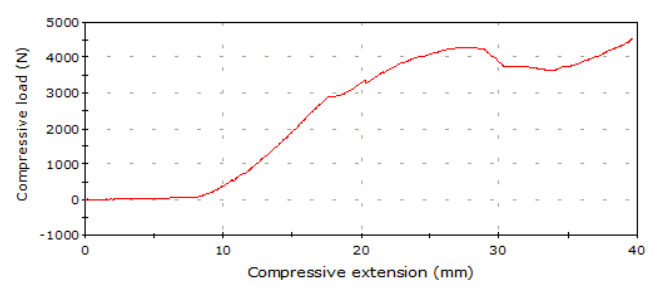

C

Figure 1c: Influence of Tillage Practice $C$ on Compression Test of TMS 0581 Cassava Tubers for a Rain Fed Soil + $622.50 \mathrm{~kg} / \mathrm{ha}$ Fertilizer. excluding tillage practices $\mathrm{A}$ and $\mathrm{D}$ which presented dissimilar values of compressive extension at break (standard). These results reveal that A and D tillage practices produce cassava tubers which tend to have higher mechanical properties compared to other tillage practices. These cassava tubers may not be prone to damages during transportation, handling and processing processes compared to other cassava tubers from other tillage practices. This may be on the grounds that tillage affects rising movement of moisture to the soil surface, vapour transfer from the surface to the atmosphere, heat transfer to the soil, provides an ideal opportunity to break up nutrients formed in the deep zones of the soil, and disrupts pests and pathogen cycles. These results are in accordance with discoveries by different analysts (Kolawole et al., 2010; Adetan et al., 2003).

D

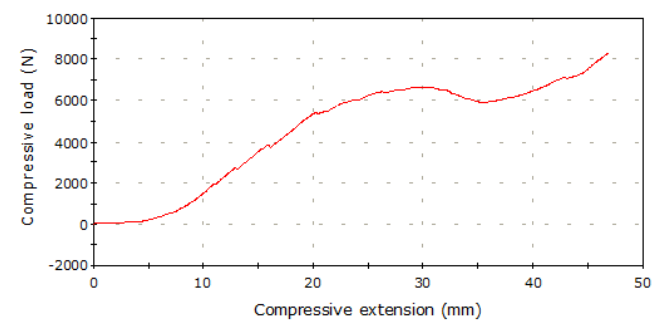

Figure 1d: Influence of Tillage Practice D on Compression Test of TMS 0581 Cassava Tubers for a Rain Fed Soil + $622.50 \mathrm{~kg} / \mathrm{ha}$ Fertilizer.

E

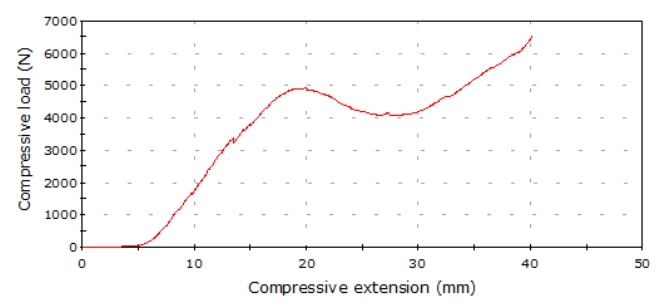

$E$

Figure 1e: Influence of Tillage Practice $E$ on Compression Test of TMS 0581 Cassava Tubers for a Rain Fed Soil $+622.50 \mathrm{~kg} / \mathrm{ha}$ Fertilizer.

$\mathrm{F}$

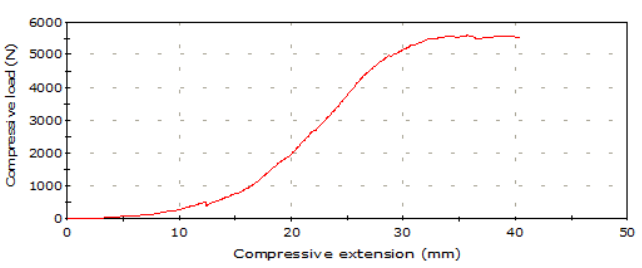

$\mathrm{F}$

Figure 1f: Influence of Tillage Practice $F$ on Compression Test of TMS 0581 Cassava Tubers for a Rain Fed Soil + $622.50 \mathrm{~kg} / \mathrm{ha}$ Fertilizer. 
G

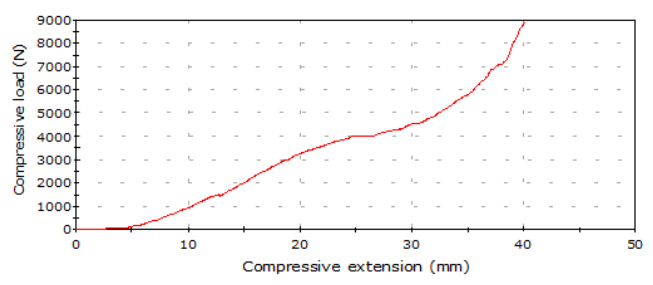

G

Figure 1a: Influence of Tillage Practice G on Compression Test of TMS 0581 Cassava Tubers for a Rain Fed Soil $+622.50 \mathrm{~kg} / \mathrm{ha}$ Fertilizer.

D. The Effect of Tillage Practices on physical properties of TMS 0581 Cassava Tubers under a Rain-fed + $622.50 \mathrm{~kg} / \mathrm{ha}$ Fertilizer for Planting Season 2015/2016.

The result of tillage practices on physical properties of TMS 0581 cassava tubers for a rain-fed $+622.50 \mathrm{~kg} / \mathrm{ha}$ fertilizer for planting season 2015/2016 are presented in Table 5 . There was significant $(\mathrm{p}<0.05)$ effect of tillage practices on the size of cassava tubers. F tillage practice presented the peak size of $12.46 \pm 0.60^{\mathrm{c}} \mathrm{cm}$, followed by G, E, C, B, H and D tillage practices of sizes $10.88 \pm 0.65^{\mathrm{c}} \mathrm{cm}, 8.79 \pm 0.65^{\mathrm{b}} \mathrm{cm}$, $8.64 \pm 0.31^{\mathrm{ab}} \mathrm{cm}, 8.49 \pm 0.96^{\mathrm{ab}} \mathrm{cm}, 8.25 \pm 0.64^{\mathrm{ab}} \mathrm{cm}$ and $7.71 \pm 0.38^{\mathrm{ab}} \mathrm{cm}$ respectively while A tillage practice gave the lowest size of $6.88 \pm 0.66^{\mathrm{a}} \mathrm{cm}$. These outcomes uncovered that the F tillage practice arranged a decent seedbed which grants appropriate condition for advancement and development of the yield. These outcomes likewise concurred with the discoveries of different specialists (Kolawole et al., 2010, Ohwovoriole et al., 1988; Adetan et al., 2006; Kamal and Oyelade, 2010), who discovered wide inconsistencies in the size of the tubers.

There was significant $(\mathrm{p}<0.05)$ influence of tillage practices on the surface area of cassava tubers. $F$ tillage practice presented the peak surface area of $496.53 \pm 44.24^{\mathrm{c}} \mathrm{cm}^{2}$, followed by G, E, B, C, H and D tillage practices of surface area $387.58 \pm 46.01^{\mathrm{b}} \mathrm{cm}^{2}, 256.06 \pm 36.10^{\mathrm{a}} \mathrm{cm}^{2}, 246.59 \pm 50.27^{\mathrm{a}}$ $\mathrm{cm}^{2}, \quad 238.56 \pm 16.68^{\mathrm{a}} \mathrm{cm}^{2}, \quad 222.99 \pm 33.32 \quad \mathrm{a} \mathrm{cm}^{2}$ and $191.98 \pm 18.64^{\mathrm{a}} \mathrm{cm}^{2}$ respectively however A tillage practice gave the lowermost surface area of $159.31 \pm 30.47^{\mathrm{a}} \mathrm{cm}^{2}$. These results revealed that the tillage practice prepared a fine seedbed for ideal germination and better start of the seedlings. Earlier study observed wide variations in the thickness of the peel across different varieties of the crop which follows the result obtained in this research (Ohwovoriole et al., 1988; Oriola and Raji, 2013).

There was significant $(\mathrm{p}<0.05)$ effect of tillage practices on the sphericity of cassava tubers. G tillage practice gave the highest sphericity of $44.29 \pm 2.87^{\mathrm{d}} \%$, followed by D, F, C, E, $\mathrm{H}$ and $\mathrm{B}$ tillage practices of sphericity $39.35 \pm 2.13^{\mathrm{ab}} \%$, $38.62 \pm 3.20^{\text {cd }} \%, \quad 36.95 \pm 2.12^{\text {bcd }} \%, \quad 33.39 \pm 1.20^{\text {abc }} \%$, $31.82 \pm 3.64^{\text {abc }} \%$ and $29.68 \pm 2.23^{\text {ab }} \%$ respectively whereas A tillage practice gave the lowest sphericity of $28.42 \pm 0.71^{\mathrm{a}} \%$.
$\mathrm{H}$

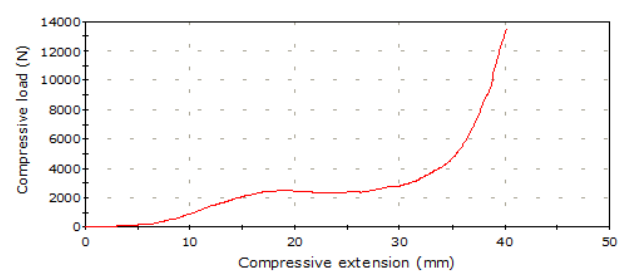

$\mathrm{H}$

Figure 1h: Influence of Tillage Practice $\mathrm{H}$ on Compression Test of TMS 0581 Cassava Tubers for a Rain Fed Soil $+622.50 \mathrm{~kg} / \mathrm{ha}$ Fertilizer.

These results showed that the $\mathrm{G}$ tillage practice combines the good effect of surface planting with the conservation features of contour listing hence the physical condition of the soil on the ridge is least affected, in which, ridges are formed with a traditional hoe. The ridges are built on the contour and the stems are planted on the ridges manually. This system is most suited for areas of high rainfall. Previous study by Adetan $e t$ al., 2006; Kamal and Oyelade (2010) also supports the results of this study.

There was significant $(p<0.05)$ effect of tillage practices on the roundness of cassava tubers. A tillage practice gave the highest roundness of $90.62 \pm 19.87^{\mathrm{d}}$, followed by H, E, F, C, B and $G$ tillage practices of roundness $71.37 \pm 17.93^{\text {cd }}$, $44.45 \pm 8.41^{\mathrm{bc}}, 40.71 \pm 11.19^{\mathrm{ab}}, 35.74 \pm 5.43^{\mathrm{ab}}, 30.20 \pm 7.19^{\mathrm{ab}}$ and $14.47 \pm 1.50^{\text {ab }}$ respectively whereas D tillage practices gave the lowest roundness of $12.24 \pm 1.84^{\mathrm{a}}$. These results demonstrated that A tillage practice improves the physical condition by controlling and thrashing the dirt, which gives reasonable condition to germination and development and supplies free oxygen and accessibility of soil dampness and fundamental supplements to plants. These findings are in consistence with that of the discoveries of (Ohwovoriole et al., 1988; Oriola and Raji, 2013; Adetan et al., 2006), who discovered fluctuated differences in the thickness of the strip crosswise over various assortments of the yield.

There was significant $(\mathrm{p}<0.05)$ outcome of tillage practices on the bulk mass of cassava tubers. $\mathrm{G}$ tillage practice gave the maximum bulk mass of $9.43^{\mathrm{h}} \mathrm{kg}$, followed by F, C, $\mathrm{E}, \mathrm{H}, \mathrm{A}$ and D tillage practices of bulk mass $8.79^{\mathrm{g}} \mathrm{kg}, 7.56^{\mathrm{f}} \mathrm{kg}$, $6.05^{\mathrm{e}} \mathrm{kg}, 4.97^{\mathrm{d}} \mathrm{kg}, 4.41^{\mathrm{c}} \mathrm{kg}$ and $3.99^{\mathrm{b}} \mathrm{kg}$ respectively however $\mathrm{B}$ tillage practice gave the lowest bulk mass of $3.88^{\mathrm{a}} \mathrm{kg}$. These findings indicated that the $G$ tillage practice joins the great impact of surface planting with the protection highlights of shape posting henceforth the physical state of the dirt on the edge is smallest influenced. These results agree with that of the findings of Jongruaysup et al. (2007), who stated that the fresh root yield of cassava (Manihot esculenta Crantz.) grownup beneath zero tillage system was significantly greater than that of cassava grown using conventional tillage on fine loamy soil (Oxic Paleustults) in Thailand. 
There was significant $(\mathrm{p}<0.05)$ effect of tillage practices on the coefficient of friction of cassava tubers. A tillage practice presented the highest coefficient of friction of $3.59 \pm 0.19^{\mathrm{b}}$, tailed by D, E, C, G, B and F tillage practices of coefficient of static friction $3.13 \pm 0.15^{\mathrm{a}}, \quad 3.07 \pm 0.26^{\mathrm{a}}$, $3.00 \pm 0.09^{\mathrm{a}}, \quad 2.84 \pm 0.08^{\mathrm{a}}, \quad 2.83 \pm 0.06^{\mathrm{a}}$ and $2.81 \pm 0.13^{\mathrm{a}}$ respectively however $\mathrm{H}$ tillage practice gave the lowest coefficient of static friction of $2.69 \pm 0.07^{\mathrm{a}}$. These results indicated that A tillage practice provide the highest value of coefficient of friction of cassava tubers. The coefficient of friction between the granular materials is equal to the tangent of the angles of the internal friction for the materials; when tubers started to motion, the tangent of slip angle shows it coefficient of friction. The outcome in this research follows the study other researchers (Nwagugu and Okonkwo, 2009; Sajeev et al., 2009).

Table 5: Effect of tillage methods on physical properties of TMS 0581 cassava tubers under a rain fed soil $+622.50 \mathrm{~kg} / \mathrm{ha}$ fertilizer $(2015 / 2016$ planting season).

\begin{tabular}{|c|c|c|c|c|c|c|c|c|}
\hline $\begin{array}{l}\text { Parame- } \\
\text { ters }\end{array}$ & $\mathbf{A}$ & B & $\mathbf{C}$ & D & $\mathbf{E}$ & $\mathbf{F}$ & $\mathbf{G}$ & $\mathbf{H}$ \\
\hline $\mathrm{L}(\mathrm{cm})$ & $24.61 \pm 2.78^{\mathrm{ab}}$ & $30.13 \pm 4.06^{\mathrm{bc}}$ & $24.58 \pm 1.75^{\mathrm{ab}}$ & $20.18 \pm 1.43^{\mathrm{a}}$ & $26.66 \pm 2.19^{a b c}$ & $34.26 \pm 3.54^{\mathrm{c}}$ & $25.80 \pm 2.21^{\mathrm{ab}}$ & $29.25 \pm 4.57^{\mathrm{bc}}$ \\
\hline $\mathrm{W}(\mathrm{cm})$ & $3.85 \pm 0.36^{\mathrm{a}}$ & $4.93 \pm 0.57^{\mathrm{ab}}$ & $6.82 \pm 0.26^{\mathrm{c}}$ & $5.52 \pm 0.31^{\mathrm{b}}$ & $5.45 \pm 0.40^{\mathrm{b}}$ & $8.73 \pm 0.68^{\mathrm{d}}$ & $7.87 \pm 0.49^{\text {cd }}$ & $4.98 \pm 0.23^{\mathrm{ab}}$ \\
\hline $\mathrm{T}(\mathrm{cm})$ & $3.45 \pm 0.30^{\mathrm{a}}$ & $4.22 \pm 0.48^{\mathrm{ab}}$ & $4.05 \pm 0.29^{\mathrm{ab}}$ & $4.20 \pm 0.24^{\mathrm{ab}}$ & $4.73 \pm 0.37^{b}$ & $6.76 \pm 0.28^{c}$ & $6.50 \pm 0.35^{\mathrm{c}}$ & $4.05 \pm 0.17^{\mathrm{ab}}$ \\
\hline $\mathrm{DG}(\mathrm{cm})$ & $6.88 \pm 0.66^{\mathrm{a}}$ & $8.49 \pm 0.96^{\mathrm{ab}}$ & $8.64 \pm 0.31^{\mathrm{ab}}$ & $7.71 \pm 0.38^{\mathrm{ab}}$ & $8.79 \pm 0.65^{b}$ & $12.46 \pm 0.60^{\mathrm{c}}$ & $10.88 \pm 0.65^{\mathrm{c}}$ & $8.25 \pm 0.64^{\mathrm{ab}}$ \\
\hline $\operatorname{AR}(\%)$ & $16.01 \pm 0.63^{\mathrm{a}}$ & $17.62 \pm 1.90^{\mathrm{a}}$ & $29.93 \pm 2.47^{c}$ & $28.53 \pm 2.24^{\mathrm{cd}}$ & $20.86 \pm 1.14^{\mathrm{ab}}$ & $28.25 \pm 4.44^{\mathrm{cd}}$ & $32.93 \pm 3.36^{\mathrm{d}}$ & $20.50 \pm 3.61^{\mathrm{ab}}$ \\
\hline $\mathrm{SA}\left(\mathrm{cm}^{2}\right)$ & $159.31 \pm 30.47^{\mathrm{a}}$ & $246.59 \pm 50.27^{\mathrm{a}}$ & $238.56 \pm 16.68^{\mathrm{a}}$ & $191.98 \pm 18.64^{\mathrm{a}}$ & $256.06 \pm 36.10^{\mathrm{a}}$ & $496.53 \pm 44.24^{c}$ & $\begin{array}{l}387.58 \pm 46.0 \\
1^{\mathrm{b}}\end{array}$ & $222.99 \pm 33.32^{\mathrm{a}}$ \\
\hline $\mathrm{SP}(\%)$ & $28.42 \pm 0.71^{\mathrm{a}}$ & $29.68 \pm 2.23^{\mathrm{ab}}$ & $36.95 \pm 2.12^{\text {bcd }}$ & $39.35 \pm 2.13^{\mathrm{ab}}$ & $33.39 \pm 1.20^{\mathrm{abc}}$ & $38.62 \pm 3.20^{\mathrm{cd}}$ & $44.29 \pm 2.87^{\mathrm{d}}$ & $31.82 \pm 3.64^{\mathrm{abc}}$ \\
\hline $\mathrm{R}$ & $90.62 \pm 19.87^{\mathrm{d}}$ & $30.20 \pm 7.19^{\mathrm{ab}}$ & $35.74 \pm 5.43^{\mathrm{ab}}$ & $12.24 \pm 1.84^{\mathrm{a}}$ & $44.45 \pm 8.41^{\mathrm{bc}}$ & $40.71 \pm 11.19^{\mathrm{ab}}$ & $14.47 \pm 1.50^{\mathrm{ab}}$ & $71.37 \pm 17.93^{\mathrm{cd}}$ \\
\hline M (kg) & $0.49 \pm 0.10^{\mathrm{ab}}$ & $0.48 \pm 0.07^{\mathrm{ab}}$ & $0.52 \pm 0.06^{\mathrm{a}}$ & $0.31 \pm 0.04^{\mathrm{ab}}$ & $0.55 \pm 0.14^{\mathrm{ab}}$ & $1.12 \pm 0.17^{\mathrm{c}}$ & $0.76 \pm 0.14^{\mathrm{ab}}$ & $0.32 \pm 0.07^{\mathrm{a}}$ \\
\hline $\mathrm{V}\left(\mathrm{m}^{3}\right)$ & $0.44 \pm 0.10^{\mathrm{ab}}$ & $0.33 \pm 0.07^{\mathrm{a}}$ & $0.41 \pm 0.13^{\mathrm{ab}}$ & $0.27 \pm 0.04^{\mathrm{a}}$ & $0.53 \pm 0.12^{\mathrm{ab}}$ & $1.18 \pm 0.19^{c}$ & $0.78 \pm 0.15^{\mathrm{b}}$ & $0.29 \pm 0.06^{\mathrm{a}}$ \\
\hline $\mathrm{TD}\left(\mathrm{kg} / \mathrm{m}^{3}\right)$ & $1.20 \pm 0.08^{\mathrm{a}}$ & $1.61 \pm 0.11^{\mathrm{ab}}$ & $2.46 \pm 0.59^{b}$ & $1.19 \pm 0.14^{\mathrm{a}}$ & $0.96 \pm 0.06^{\mathrm{a}}$ & $1.02 \pm 0.08^{\mathrm{aa}}$ & $1.47 \pm 0.54^{\mathrm{ab}}$ & $1.17 \pm 0.12^{\mathrm{a}}$ \\
\hline BM (kg) & $4.41^{\mathrm{c}}$ & $3.88^{\mathrm{a}}$ & $7.56^{\mathrm{f}}$ & $3.99^{\mathrm{b}}$ & $6.05^{\mathrm{e}}$ & $8.79^{g}$ & $9.43^{\mathrm{h}}$ & $4.97^{\mathrm{d}}$ \\
\hline $\operatorname{BV}\left(\mathrm{m}^{3}\right)$ & $4.10^{\mathrm{c}}$ & $3.60^{\mathrm{a}}$ & $6.20^{\mathrm{f}}$ & $3.92^{\mathrm{b}}$ & $5.94^{\mathrm{e}}$ & $9.20^{\mathrm{g}}$ & $9.80^{\mathrm{h}}$ & $4.60^{\mathrm{d}}$ \\
\hline $\mathrm{BD}\left(\mathrm{kg} / \mathrm{m}^{3}\right)$ & $1.08^{\mathrm{d}}$ & $1.22^{\mathrm{d}}$ & $1.08^{\mathrm{e}}$ & $1.02^{\mathrm{c}}$ & $1.02^{\mathrm{c}}$ & $0.96^{\mathrm{a}}$ & $0.96^{\mathrm{a}}$ & $1.08^{\mathrm{d}}$ \\
\hline $\begin{array}{l}\mathrm{P}(\%) \\
\operatorname{AP}\left({ }^{0}\right)\end{array}$ & $\begin{array}{l}7.83 \pm 4.92^{\mathrm{a}} \\
69.78 \pm 0.38^{\mathrm{bc}}\end{array}$ & $\begin{array}{l}30.80 \pm 4.88^{\mathrm{a}} \\
70.00 \pm 0.42^{\mathrm{bc}}\end{array}$ & $\begin{array}{l}-6.98 \pm 31.93^{\mathrm{a}} \\
68.41 \pm 0.42^{\mathrm{ab}}\end{array}$ & $\begin{array}{l}-4.30 \pm 14.94^{\mathrm{a}} \\
69.20 \pm 0.29^{\mathrm{bc}}\end{array}$ & $\begin{array}{l}-10.89 \pm 7.60^{\mathrm{a}} \\
69.00 \pm 0.50^{\mathrm{ab}}\end{array}$ & $\begin{array}{l}-1.95 \pm 13.98^{\mathrm{a}} \\
68.09 \pm 0.46^{\mathrm{a}}\end{array}$ & $\begin{array}{l}- \\
38.01 \pm 45.23^{\mathrm{a}} \\
70.64 \pm 0.72^{\mathrm{cd}}\end{array}$ & $\begin{array}{l}-5.42 \pm 18.49^{\mathrm{a}} \\
71.75 \pm 0.45^{\mathrm{d}}\end{array}$ \\
\hline $\mathrm{CF}$ & $3.59 \pm 0.19^{\mathrm{b}}$ & $2.83 \pm 0.06^{\mathrm{a}}$ & $3.00 \pm 0.09^{\mathrm{a}}$ & $3.13 \pm 0.15^{\mathrm{a}}$ & $3.07 \pm 0.26^{\mathrm{a}}$ & $2.81 \pm 0.13^{\mathrm{a}}$ & $2.84 \pm 0.08^{\mathrm{a}}$ & $2.69 \pm 0.07^{\mathrm{a}}$ \\
\hline
\end{tabular}

Values are means for triplicates and standard error. Means values including distinctive superscript inside a similar line are altogether significant (P<0.05).

E. Influence of Tillage Practices on Physical Properties of TMS 0581 Cassava Tubers under the Rain-fed Soil + $0 \mathrm{~kg} / \mathrm{ha}$ Fertilizer.

The effect of tillage methods on physical properties of TMS 0581 cassava tubers for a rain-fed $+0 \mathrm{~kg} / \mathrm{ha}$ fertilizer for planting season 2014/2015 are presented in Table 6. There was significant $(p<0.05)$ effect of tillage practices on the size of cassava tubers. $\mathrm{G}$ tillage practice presented the peak size of $10.52 \pm 1.02^{\mathrm{d}} \mathrm{cm}$, followed by $\mathrm{E}, \mathrm{F}, \mathrm{A}, \mathrm{H}, \mathrm{B}$ and $\mathrm{C}$ tillage practices of size $10.43 \pm 0.72^{\mathrm{d}} \mathrm{cm}, 10.35 \pm 0.95^{\mathrm{d}} \mathrm{cm}$, $9.80 \pm 0.88^{\mathrm{ab}} \mathrm{cm}, 9.61 \pm 0.71^{\mathrm{bcd}} \mathrm{cm}, 9.12 \pm 0.62^{\mathrm{cd}} \mathrm{cm}$ and $8.51 \pm 0.75^{\mathrm{a}} \mathrm{cm}$ respectively although $\mathrm{D}$ tillage practice offered the lowest size of $7.84 \pm 0.38^{\mathrm{abc}} \mathrm{cm}$. These results showed that the $\mathrm{G}$ tillage practice gave the maximum size. The results are alike with that of the findings of Adetan et al. (2006); Kamal and Oyelade (2010), who observed anomaly in the size of the tubers across diverse varieties of the crop.

$\mathrm{G}$ tillage practice gave the highest surface area of $370.65 \pm 67.18^{\mathrm{c}} \mathrm{cm}^{2}$, followed by E, F, A, H, B and C tillage practices of surface area $358.67 \pm 50.33^{\mathrm{c}} \mathrm{cm}^{2}, 356.37 \pm 58.60^{\mathrm{c}}$ $\mathrm{cm}^{2}, \quad 319.05 \pm 55.06^{\mathrm{ab}} \quad \mathrm{cm}^{2}, \quad 311.10 \pm 42.29^{\mathrm{bc}} \quad \mathrm{cm}^{2}$, $272.16 \pm 34.72^{\mathrm{ab}} \mathrm{cm}^{2}$ and $241.87 \pm 42.09^{\mathrm{a}} \mathrm{cm}^{2}$ respectively but $D$ tillage practice gave the lowest surface area of $198.32 \pm 19.79^{\mathrm{a}} \mathrm{cm}^{2}$. These results showed that the $\mathrm{G}$ tillage practice gave can decrease water runoff from fields and provides a slower but more even rate of nutrient release. These results agree with that of the findings of Adetan et al. (2006); Kamal and Oyelade (2010), who detected indiscretion in the thickness of the peel across different varieties of the crop. 
F tillage practice gave the peak sphericity of $58.19 \pm 4.65^{\mathrm{c}} \%$, followed by E, H, B, G, D and A tillage practices of sphericity $56.48 \pm 3.84^{\mathrm{c}} \%, \quad 50.07 \pm 2.85^{\mathrm{bc}} \%, \quad 49.62 \pm 4.69^{\mathrm{bc}} \%$, $44.10 \pm 4.11^{\mathrm{ab}} \%, 40.88 \pm 1.79^{\mathrm{ab}} \%$ and $36.86 \pm 2.76^{\mathrm{a}} \%$ respectively however Manual Ridging (C) tillage practice presented the lowermost sphericity of $34.43 \pm 2.97^{\mathrm{a}} \%$. These results specified that the $\mathrm{F}$ tillage practice arranged a good seedbed suitable for germination and better start of the seedlings. These results are like that of the findings of (Kolawole et al., 2010; Oriola and Raji, 2013; Kamal and Oyelade, 2010), who observed wide variations in the size and shape of cassava tubers.C tillage practice gave the highest roundness of $28.59 \pm 7.20^{\circ}$, followed by A, G, D, B, H and E tillage practices of roundness $21.86 \pm 4.76^{\mathrm{bc}}, 19.82 \pm 6.49^{\mathrm{abc}}$, $14.62 \pm 2.12^{\mathrm{ab}}, 11.03 \pm 2.94^{\mathrm{ab}}, 10.73 \pm 1.31^{\mathrm{ab}}$ and $9.35 \pm 2.22^{\mathrm{a}}$ respectively whereas Minimum Tillage (D) tillage practice gave the lowest roundness of $8.61 \pm 3.18^{\mathrm{a}}$.

The results revealed that Manual ridging (C) combines the good effect of surface planting with the conservation features of contour listing hence the physical condition of the soil on the ridge is least affected. The results are similar with that of the findings of Adetan et al. (2006); Kamal and Oyelade (2010), who observed anomaly in the shape of the tubers across different varieties of the crop.
E tillage practice gave the highest bulk mass of $7.84^{\mathrm{h}} \mathrm{kg}$; followed by H, B, F, A, G and C tillage practices of bulk mass $7.74^{\mathrm{g}} \mathrm{kg}, 6.23^{\mathrm{f}} \mathrm{kg}, 5.86^{\mathrm{e}} \mathrm{kg}, 5.60^{\mathrm{d}} \mathrm{kg}, 5.50^{\mathrm{c}} \mathrm{kg}$ and $5.05^{\mathrm{b}} \mathrm{kg}$ correspondingly while D tillage practice gave the lowest bulk mass of $4.27^{\mathrm{a}} \mathrm{kg}$. These results revealed that the E tillage practice break through and shatter plough soles and layers impermeable soil horizons or other barriers to the movement of moisture and roots through the soil profile, thus providing suitable and conducive environment for the cassava plant growth and development which resulted in the greatest yield of tillage practice $\mathrm{E}$.

These results agree with that of the findings of Jongruaysup et al. (2007), who stated that the fresh root produce of cassava (Manihot esculenta $C$.) grown beneath zero tillage system was meaningfully greater than that of cassava fully-fledged using conventional tillage on fine loamy soil (Oxic Paleustults) in Thailand. A tillage practice gave the maximum coefficient of static friction of $2.87 \pm 0.05^{\mathrm{c}}$; followed C, B, G, H, D and E tillage practices of coefficient of static friction $2.86 \pm 0.06^{\mathrm{c}}, 2.67 \pm 0.05^{\mathrm{b}}, 2.62 \pm 0.05^{\mathrm{ab}}, 2.62 \pm 0.06^{\mathrm{ab}}$, $2.53 \pm 0.05^{\mathrm{ab}}$ and $2.51 \pm 0.05^{\mathrm{ab}}$ respectively however $\mathrm{F}$ tillage practice presented the minimum coefficient of static friction of $2.49 \pm 0.06^{\mathrm{a}}$. These results reveal that the tillage practice A gave the highest value of coefficient of friction of cassava tubers. The results corroborate the findings of Mohsenin, 2010.

Table 6: Effect of tillage methods on physical properties of TMS 0581 cassava tubers for a rain-fed soil + $0 \mathrm{~kg} / \mathrm{ha}$ fertilizer (2014/2015).

\begin{tabular}{|c|c|c|c|c|c|c|c|c|}
\hline Parameter & $\mathbf{A}$ & B & $\mathbf{C}$ & D & $\mathbf{E}$ & $\mathbf{F}$ & $\mathbf{G}$ & $\mathbf{H}$ \\
\hline $\mathrm{L}(\mathrm{cm})$ & $26.96 \pm 2.02^{\mathrm{b}}$ & $20.70 \pm 3.21^{\mathrm{ab}}$ & $26.00 \pm 3.30^{\mathrm{ab}}$ & $19.39 \pm 0.99^{\mathrm{ab}}$ & $19.46 \pm 2.06^{\mathrm{ab}}$ & $18.70 \pm 2.55^{\mathrm{a}}$ & $25.52 \pm 3.74^{\mathrm{ab}}$ & $20.13 \pm 2.02^{\mathrm{ab}}$ \\
\hline $\mathrm{W}(\mathrm{cm})$ & $6.87 \pm 0.78^{\mathrm{ab}}$ & $7.25 \pm 0.42^{\mathrm{ab}}$ & $5.54 \pm 0.60^{\mathrm{a}}$ & $5.76 \pm 0.39^{a}$ & $8.36 \pm 0.69^{b}$ & $8.33 \pm 0.88^{b}$ & $7.21 \pm 0.59^{\mathrm{ab}}$ & $7.13 \pm 0.49^{\mathrm{ab}}$ \\
\hline $\mathrm{T}(\mathrm{cm})$ & $5.25 \pm 0.63^{\mathrm{ab}}$ & $5.41 \pm 0.33^{\mathrm{ab}}$ & $4.49 \pm 0.39^{\mathrm{ab}}$ & $4.39 \pm 0.23^{\mathrm{a}}$ & $7.28 \pm 0.55^{\mathrm{b}}$ & $7.42 \pm 0.77^{\mathrm{b}}$ & $6.52 \pm 0.56^{b}$ & $6.38 \pm 0.47^{\mathrm{ab}}$ \\
\hline $\mathrm{DG}(\mathrm{cm})$ & $9.80 \pm 0.88^{\mathrm{ab}}$ & $9.12 \pm 0.62^{\mathrm{cd}}$ & $8.51 \pm 0.75^{\mathrm{a}}$ & $7.84 \pm 0.38^{\mathrm{abc}}$ & $10.43 \pm 0.72^{\mathrm{d}}$ & $10.35 \pm 0.95^{\mathrm{d}}$ & $10.52 \pm 1.02^{\mathrm{abc}}$ & $9.61 \pm 0.71^{\mathrm{bcd}}$ \\
\hline $\operatorname{AR}(\%)$ & $25.97 \pm 2.81^{\mathrm{a}}$ & $41.37 \pm 5.47^{\mathrm{ab}}$ & $22.79 \pm 3.17^{\mathrm{a}}$ & $30.06 \pm 2.07^{\mathrm{ab}}$ & $46.28 \pm 4.77^{b}$ & $47.51 \pm 5.39^{b}$ & $31.43 \pm 4.52^{\mathrm{b}}$ & $38.17 \pm 3.26^{\mathrm{ab}}$ \\
\hline $\mathrm{SA}\left(\mathrm{cm}^{2}\right)$ & $319.05 \pm 55.06^{\mathrm{ab}}$ & $272.16 \pm 34.72^{\mathrm{ab}}$ & $241.87 \pm 42.09^{\mathrm{a}}$ & $198.32 \pm 19.79^{a}$ & $358.67 \pm 50.33^{c}$ & $356.37 \pm 58.60^{c}$ & $370.65 \pm 67.18^{\mathrm{bc}}$ & $311.10 \pm 42.29^{b c}$ \\
\hline $\mathrm{SP}(\%)$ & $36.86 \pm 2.76^{\mathrm{a}}$ & $49.62 \pm 4.69^{\mathrm{bc}}$ & $34.43 \pm 2.97^{\mathrm{a}}$ & $40.88 \pm 1.79^{\mathrm{ab}}$ & $56.48 \pm 3.84^{\mathrm{c}}$ & $58.19 \pm 4.65^{\mathrm{c}}$ & $44.10 \pm 4.11^{\mathrm{ab}}$ & $50.07 \pm 2.85^{\mathrm{bc}}$ \\
\hline $\mathrm{R}$ & $21.86 \pm 4.76^{\mathrm{bc}}$ & $11.03 \pm 2.94^{\mathrm{ab}}$ & $28.59 \pm 7.20^{\mathrm{c}}$ & $14.62 \pm 2.12^{\mathrm{ab}}$ & $9.35 \pm 2.22^{\mathrm{a}}$ & $8.61 \pm 3.18^{\mathrm{a}}$ & $19.82 \pm 6.49^{\mathrm{abc}}$ & $10.73 \pm 1.31^{\mathrm{ab}}$ \\
\hline $\mathrm{M}(\mathrm{kg})$ & $0.70 \pm 0.15^{\mathrm{a}}$ & $0.62 \pm 0.13^{\mathrm{a}}$ & $0.56 \pm 0.09^{\mathrm{a}}$ & $0.35 \pm 0.05^{\mathrm{a}}$ & $0.75 \pm 0.16^{\mathrm{a}}$ & $0.75 \pm 0.16^{\mathrm{a}}$ & $0.75 \pm 0.17^{\mathrm{a}}$ & $0.55 \pm 0.10^{\mathrm{a}}$ \\
\hline $\mathrm{V}\left(\mathrm{m}^{3}\right)$ & $0.67 \pm 0.17^{\mathrm{a}}$ & $0.47 \pm 0.09^{\mathrm{a}}$ & $0.55 \pm 0.09^{\mathrm{a}}$ & $0.33 \pm 0.03^{\mathrm{a}}$ & $0.65 \pm 0.14^{\mathrm{a}}$ & $0.66 \pm 0.15^{\mathrm{a}}$ & $0.65 \pm 0.14^{\mathrm{a}}$ & $0.48 \pm 0.09^{\mathrm{a}}$ \\
\hline $\begin{array}{l}\mathrm{TD} \\
\left(\mathrm{kg} / \mathrm{m}^{3}\right)\end{array}$ & $1.15 \pm 0.11^{\mathrm{ab}}$ & $1.33 \pm 0.09^{\mathrm{b}}$ & $1.01 \pm 0.06^{\mathrm{a}}$ & $1.15 \pm 0.06^{\mathrm{ab}}$ & $1.16 \pm 0.02^{\mathrm{ab}}$ & $1.15 \pm 0.02^{\mathrm{ab}}$ & $1.15 \pm 0.02^{\mathrm{ab}}$ & $1.16 \pm 0.01^{\mathrm{ab}}$ \\
\hline BM (kg) & $5.60^{d}$ & $6.23^{\mathrm{f}}$ & $5.05^{\mathrm{b}}$ & $4.27^{\mathrm{a}}$ & $7.84^{\mathrm{h}}$ & $5.86^{\mathrm{e}}$ & $5.50^{c}$ & $7.74^{\mathrm{g}}$ \\
\hline $\mathrm{BV}\left(\mathrm{m}^{3}\right)$ & $5.40^{\mathrm{d}}$ & $6.00^{\mathrm{f}}$ & $4.90^{\mathrm{b}}$ & $4.20^{\mathrm{a}}$ & $7.70^{\mathrm{h}}$ & $5.70^{\mathrm{e}}$ & $5.40^{\mathrm{c}}$ & $7.64^{\mathrm{g}}$ \\
\hline $\begin{array}{l}\mathrm{BD} \\
\left(\mathrm{kg} / \mathrm{m}^{3}\right)\end{array}$ & $1.06^{\mathrm{b}}$ & $1.45^{\mathrm{f}}$ & $1.03^{\mathrm{a}}$ & $1.19^{\mathrm{e}}$ & $1.11^{\mathrm{c}}$ & $1.11^{\mathrm{d}}$ & $1.11^{\mathrm{d}}$ & $1.11^{\mathrm{c}}$ \\
\hline $\mathrm{P}(\%)$ & $3.12 \pm 7.54^{\mathrm{b}}$ & $-14.14 \pm 8.51^{\mathrm{a}}$ & $-4.63 \pm 6.42^{\mathrm{ab}}$ & $-6.19 \pm 5.98^{a b}$ & $4.22 \pm 1.26^{\mathrm{b}}$ & $3.54 \pm 1.82^{\mathrm{b}}$ & $3.14 \pm 1.79^{\mathrm{b}}$ & $4.17 \pm 1.04^{\mathrm{b}}$ \\
\hline $\operatorname{AP}\left({ }^{0}\right)$ & $70.75 \pm 0.03^{c}$ & $69.40 \pm 0.37^{\mathrm{b}}$ & $70.67 \pm 0.33^{\mathrm{c}}$ & $68.33 \pm 0.38^{\mathrm{ab}}$ & $68.18 \pm 0.38^{\mathrm{ab}}$ & $68.00 \pm 0.40^{\mathrm{a}}$ & $69.00 \pm 0.37^{\mathrm{ab}}$ & $69.00 \pm 0.46^{\mathrm{ab}}$ \\
\hline $\mathrm{CF}$ & $2.87 \pm 0.05^{\mathrm{c}}$ & $2.67 \pm 0.05^{\mathrm{b}}$ & $2.86 \pm 0.06^{\mathrm{c}}$ & $2.53 \pm 0.05^{\mathrm{ab}}$ & $2.51 \pm 0.05^{\mathrm{ab}}$ & $2.49 \pm 0.06^{\mathrm{a}}$ & $2.62 \pm 0.05^{\mathrm{ab}}$ & $2.62 \pm 0.06^{\mathrm{ab}}$ \\
\hline
\end{tabular}

Values are means for triplicates and standard error. Means values including distinctive superscript inside a similar line are altogether significant $(\mathrm{P}<0.05)$. 


\section{CONCLUSION}

There were significant differences among the eight tillage practices used in this study for the selected engineering properties. This indicate that tillage practices had significant influence on engineering properties of cassava tubers. Ploughing + Harrowing (A) tillage practice gave the most suitable and uniform engineering properties, followed by F, G, $\mathrm{D}, \mathrm{C}, \mathrm{E}$ and $\mathrm{H}$ tillage practices. It is therefore advisable for farmers to adopt a conventional tillage practice [Ploughing + Harrowing (A)] which will enable cassava tubers to come in uniform and suitable engineering properties which will enhanced improvement in the existing cassava peeling machines which has constitute a bottle- neck toward the full automation of the processing system. The study had provided appropriate tillage practice needed by farmers to grow cassava tubers with uniform engineering properties. It had also provided enough data for engineers to design and fabricate systems for handling and processing of cassava tubers into useful products.

\section{REFERENCES}

Adetan, D.A.; L. O. Adekoya and O. B. Aluko. (2003). Characterization of some properties of cassava root tubers. Journal of Food Engineering, 59, 349-353.

Adetan, D. A.; L. O. Adekoya and O. B. Aluko. (2006). Theory of mechanical method of peeling cassava tubers with knives. International Agrophysics, 20(4), 269 - 276.

Agbetoye, L. A. S. (2005). Improving the technology of cassava harvesting and processing mechanization for food security in Nigeria. Paper presented at the International Conference on Science and Technology, Held at the Federal University of Technology, Akure, Ondo State, Nigeria, 196 204.

Ahmad, N.; M. Rashid and A. G. Vaes. (1996). Fertilizer and their use in Pakistan, NFDC Publication No. 4/96. 2nd Ed. Islamabad. p. 274.

Akaaimo, D. I. and Raji, O. A. (2006). Some Physical Engineering Properties of Prosopsis Africana Seed. Biosystems Engineering, 95 (2): 197-205.

Bennie, T. P and F.J. P. Botha. (1986). Effect of deep tillage and controlled traffic on root growth, water use efficiency and yield of irrigated maize and wheat. Soil and Tillage Res.7: 85- 95.

Burum, S. (2004). American Cinematographer Manual (9th ed). ASC Press ISBN 0-935578-24-2.Esref, I. and Halil, U. (2007). Moisture-dependent Physical Properties of White Speckled Red Kidney Bean Grains. Journal of Food Engineering 82, 209.

Ezekwe, G. O. (1976). A feature for achieving a constant depth of peel in the Mechanical peeling of Cassava. Nigeria Journal of Engineering, 1(3):174-181.

Ezekwe, G. O. (1979). Mechanizing Cassava Peeling: The Project Development Agency (PRODA) of Cassava Nibbling Machine. PRODA Technical Reports No. 1, 1-20.
Hammel, J. E. (1989). Long term tillage and crop rotation effects on bulk density and soil impedance in Northern Idaho. Soil Sci. Soc. Am. J., 53: 1515-1519.

Igbeka, J. C. (1980). Relationship of moisture diffusivity with moisture content and temperature in cassava (Manihot Esculenta Cranz) and potato (Solarum tuberosum) during drying. Nigeria Journal of Science, 14; 27 - 36.

Igbeka, J. C. (1984). Some mechanical and rheological properties of yam and cassava. African Journal of Science and Technology, 3(2): 45-60.

Igbeka, J. C. (1985). Mechanization of tuber (cassava) peeling. Proceedings of the International Symposium on Mechanization of Harvesting and Subsequent Processing of Agricultural Products in Tropical Africa and the Manufacturing of Relevant Agricultural Implements Yaounde, Cameroon, 410-422.

Jongruaysup, S.; P. Namwong and A. Tiensiriroek. (2007). Minimum Tillage for Cassava in Thailand, in Cassava Research and Development in Asia-Exploring New Opportunities for an Ancient Crop. Proceedings of the 7th Regional Workshop, held in Bangkok, Thailand, Oct 28- Nov 1, 2002, pp. 251-263, CIAT, Bangkon, Thailand.

Kamal, A. R and Oyelade, O. A. (2010). Present status of cassava peeling in Nigeria. Journal of Agricultural Engineering and Technology, 18 (2): 7-13.

Kolawole, O. P.; L. A. S. Agbetoye and A. S. Ogunlowo. (2010). Sustaining world food security with improved cassava processing technologies: The Nigerian Experience on Sustainability, 2: 3681- 3694.

Koller, K. (2003). Techniques of soil tillage. Ed. Adel El Titi. Soil tillage in agroecosystem, CRC Press Boca Roton, FL-1-25.

Mahajan, K. K. (1996). Management of phosphorus and farmyard manure in maize-wheat system in mid hills subhumid zone of Himachal Pradesh. J. Hill Res., 9 (3): 480-485.

Mohsenin, N. N. (2010). Physical Properties of Plant and Animal Materials, Structure, Physical Characteristics and Mechanical Properties. $2^{\text {nd }}$ edition (revised); Gordon \& Breach Science Publishers, New York.

Nauda, S. K., and Mathew, G. (1996). Physical aspects of softening of cassava tubers upon fermentation with a mixed culture inoculum. Journal of Food Engineering. 29; 129 - 134.

Nwagugu, N. I., and Okonkwo, W. I. (2009). Experimental determination of comprehensive strength of sweet cassava (Manihot Esculenta Cranz). International Conference of West African Society of Agricultural Engineers and Nigerian Institution of Agricultural Engineers, 9 - 197.

Odigboh, E. U. (1983). Cassava production, processing and utilization, In: Chan Jnr, H. T. (ed.), Handbook of Tropical Foods, New York: Mercel Decker Pub. Inc., 145-200.

Ohwovoriole, E N.; S. Oboli and A. C. Mgbeke. (1988). Studies and preliminary design for a cassava tuber peeling machine. Transactions of the American Society of Agricultural Engineers (ASAE), 31(2): 380-385. 
Ohu, J. O. (2011). Tillage for Environmental Sustainability. In: Tillage for Agricultural Productivity and Environmental. Proceedings of the Nigerian Branch of International Soil Tillage Research Organization (ISTRO), University of Ilorin, Ilorin, (2011): 1-10.

Olukunle, O. J. and Akinnuli, B. O. (2012). Investigating Some Engineering Properties of Coffee Seeds and Beans. Journal of Emerging Trends in Engineering and Applied Sciences, 3 (5): 743-747.

Olukunle, O. J. and Akinnuli, B.O. (2013). Theory of an automated cassava peeling system. International Journal of Engineering and Technology (IJEIT), 2, 2277-3754.

Oluwole, O. O. and Adio, M. A. (2013). Design and construction of a batch cassava peeling machine. Journal of Mechanical Engineering and Automation, 3(1): 16-21.

Oriola, K. O. and Raji, A.O. (2013). Trends at mechanizing cassava postharvest processing operations. International Journal of Engineering and Technology (IJET), 3(9): 879-887.

Ozguven, F and Vursavus, K (2005). Some Physical, Mechanical and Aerodynamics Properties of Pine Nuts. Journal of Food Engineering, 68: 191-196.

Sajeev, M. S.; J. Sreekumar, J. Unnikrishnan, M. S. N. Moorthy and S. Shanavas. (2009). Kinetics of thermal softening of cassava tubers and rheological modeling of the starch, Journal of Food Science and Technology, 47 (5):507518 .

Tabatabaeefar, A. (2003). Moisture-Dependent Physical Properties of Wheat. International Agrophysics, 12: 207-211.

Tongglum, A.; P. Suriyapan and R. H. Howeler. (2001). "Cassava Agronomy Research and Adoption of Improved Practices in Thailand-major Achievements during the past 35 years," in Cassava's Potential in the 21st Century: Present Situation and Future Research and Development Needs. Proceedings of the 6th Regional Workshop, held in Hochi Minh City Vietnam, Feb 21- 25, 2000, pp. 228-258, CIAT, Bangkok, Thailand.

Weite, Z.; L. Xiong and L. Kimian. (1998). "Cassava Agronomy Research in China," in Cassava Breeding, Agronomy and Farmers Participatory Research in Asia. Proceedings of the 5th Regional Workshop held in Danzhou, Hainan, China, Nov 3-8, 1996, R. H. Howeler, Ed., pp. 191210, CIAT, Bangkok, Thailand.

Wright, D.; J. Marois, J. Rich and R. Sprenkel. (2008). Field corn production guide-SS-AGR- 85, Available online: http://edis.ifas. ufl.edu/ pdf files/ AG/ AG 20200. Pdf.

Yalcin, I.; C. Ozarslan and T. Akbas. (2007). Physical Properties of Pea Seed. Journal of food engineering, 79. 731732. 